This item was submitted to Loughborough's Research Repository by the author.

Items in Figshare are protected by copyright, with all rights reserved, unless otherwise indicated.

\title{
The United Kingdom Independence Party (UKIP) and the British press: integration, immigration and integrity
}

PLEASE CITE THE PUBLISHED VERSION

http://www.degruyter.com/view/product/434050

\section{PUBLISHER}

(C) Walter de Gruyter

\section{VERSION}

AM (Accepted Manuscript)

\section{PUBLISHER STATEMENT}

This work is made available according to the conditions of the Creative Commons Attribution-NonCommercialNoDerivatives 4.0 International (CC BY-NC-ND 4.0) licence. Full details of this licence are available at: https://creativecommons.org/licenses/by-nc-nd/4.0/

\section{LICENCE}

CC BY-NC-ND 4.0

\section{REPOSITORY RECORD}

Deacon, David, and Dominic Wring. 2019. "The United Kingdom Independence Party (UKIP) and the British Press: Integration, Immigration and Integrity”. figshare. https://hdl.handle.net/2134/21444. 


\section{The United Kingdom Independence Party (UKIP) and the British Press: Integration, Immigration and Integrity}

Professor David Deacon, Professor of Communication and Media Analysis, Loughborough Communication Research Centre, Department of Social Sciences, Loughborough University, d.n.deacon@,lboro.ac.uk

Dr Dominic Wring, Reader in Political Communication, as above, d.j.wring@lboro.ac.uk

\section{Introduction}

This chapter examines the emergence of the UK Independence Party (UKIP), paying particular attention to developments in its campaigning, communication and media strategies. The party was founded in 1993 as a single issue political organisation determined to secure British withdrawal from the European Union. Euro-scepticism remains at the core of the party's identity, but more recently UKIP has extended the range and breadth of its policy portfolio, introducing a distinctive, if not entirely coherent libertarian populism into the British political mainstream. Despite an unpromising start to its electoral career, the party has developed considerable political momentum and now increasingly provokes caution and even fear as opposed to ridicule on the part of its rivals.

Analysis of UKIP's rise raises questions of wider political significance. Its growing influence needs to be seen as a component element in a major shift in party politics in the UK. In the 1964 UK General Election, Labour and the Conservatives accounted for 88 percent of the vote; by 2010 this percentage had reduced to 65\% (Denver and Garnett, 2014). Given this factor and a 'first past the post' voting system, margins matter more than ever before and niche parties can no longer be dismissed as being of peripheral significance. This is particularly the case in so-called 'second order' local government and European elections. Allied to this, UKIP continues to confound what was assumed to be a well-established trend of declining rates in party membership because in 2013 its tally rose by 13,000 to 32,000, thereby making it the fourth largest in Britain (BBC, 2013). This is an instructive example of how minority parties can 'expand the ideological boundaries of a political culture and re-define the left-right spectrum providing for a new form of political behaviour, different to that of the main political parties' (Copus et al., 2009: 4).

The rapid development and impact of UKIP has brought to the fore significant tensions within the party as it tries to resolve whether it wishes to remain an 'ideological outsider' or else 
become more of a 'potential insider', that is within the mainstream (Grant, 1989). To this end, examination of UKIP's treatment by conventional journalism helps identify the tensions and contradictions in relations between the parties and the media. The latter has, like the former, been the subject of marked changes. Partly because of issues like Europe the authors have previously argued that the partisan orientations of the UK national press have become increasingly 'de-aligned' since the mid-1990s, even if their residual conservativism remains relatively undiminished (Deacon and Wring, 2002). Simultaneously, media disdain for politicians and the conduct of politics has increased. It might be supposed therefore that a strident, media conscious populist party unapologetic in its disdain for supposed 'political correctness' could provide an appealing alternative for some partisan news providers, most obviously those with strong Eurosceptic and anti-immigration propensities. But this cannot be assumed and requires further careful investigation. Before doing so, it is necessary to provide more contextual information concerning the emergence and growth of the UKIP phenomenon.

\section{The rise of Euroscepticism in the UK}

The emergence of UKIP is fundamentally entwined with the growth of debate over Britain's membership of the European Union during the last three decades. Controversy was never assuaged by the momentous 1975 referendum that confirmed the Westminster parliament's earlier decision to join the then European Economic Community. Britain has long been characterised as the 'awkward partner', the member state in the 'Big Four' most prone to debating its future inside the Union (George, 1998). Although this scepticism was traditionally articulated by rivals from across the political spectrum it began to be increasingly associated with the centre-right Conservatives who formed the government for nearly two decades from 1979 onwards. This was made obvious by the then Prime Minister Margaret Thatcher's Bruges speech in 1988, an address that proved to be a key intervention as her questioning the pace and nature of further European integration encouraged sceptical opinion to mobilize both within her party and beyond.

Given Thatcher's growing concerns over Britain's involvement in Europe, it is ironic that it was her government that had in effect reignited the issue through its then relatively uncontroversial endorsement of the 1986 Single European Act. It was this measure that encouraged federalists inside what was now know as the 'Union' rather than the 'Community' to promote the case for further and more obviously political as well as economic integration. Thatcher's growing antipathy towards EU colleagues proved to be one of the factors that led her own demise. When her former Deputy Prime Minister Geoffrey Howe resigned from 
government in 1990 and defiantly challenged her judgment on Europe it marked the beginning of the end for her own premiership. Thatcher's subsequent resignation did not, however, stem the bitterness within the Conservative party over EU integration. The issue continued to cause problems for new Prime Minister John Major, notably during the passage of the Maastricht Treaty and a preceding debate that had publicly highlighted the still deep divisions within the governing party over policy.

Although British public opinion was sceptical about further EU integration the matter was not foremost among the issues that most influence voters' decision-making. But the subject continued to feature prominently in media debates, particularly in the centre-right dominated national press. These newspapers' agenda-setting capabilities had collectively helped to reinforce what popularly became known as the Eurosceptic case. Cumulatively this also reflected and reinforced the divisions within the Conservative government over EU policy up to and including the 1997 General Election. John Major's authority over the issue was memorably challenged throughout the campaign by some of his own candidates who became increasingly vocal in stating their hostility to any further integration. Significantly these opinions found sympathy within sceptic inclined media, notably the Rupert Murdoch owned The Times, as well as two new electoral challengers who were unhappy what they perceived as the government's integrationist policies. The more prominent of these, the Referendum party led by the flamboyant entrepreneur Sir James Goldsmith, had attracted defectors from the Conservatives including a serving MP who supported his call for a plebiscite over the UK's continuing membership of the European Union. Goldsmith's well-funded intervention in the 1997 election was not decisive but it further contributed to the Conservatives' humiliating loss. It also overshadowed the campaign and electoral performance of the rival sceptic formation, the United Kingdom Independence Party. Things have, however, changed in the intervening years and where once UKIP was a secondary force in Eurosceptic terms, it is now a threat to mainstream rivals.

\section{The Gadfly That Won't Die}

Nigel Farage, the current UKIP leader, recently asserted that his organisation has 'changed the face of British politics' (Addley, 2013). This follows two decades in which political rivals, if they have commented at all, have largely sought to demean and deny the Eurosceptic party's significance. In 2004 the then leader of the Conservatives, Michael Howard, said the party was 'full of cranks and political gadflies'. Two years later his successor David Cameron dismissed UKIP as a fringe group containing 'fruitcakes, loonies and closet racists'. Since Cameron's installation as Prime Minister, several of his government colleagues have joined the 
attack. In 2013 the Tory party grandee, Kenneth Clarke, called them 'a collection of clowns'. But the frequency and nature of these and other criticisms indicates the fear that UKIP has instilled in its opponents, particularly on the centre-right from where it has been widely assumed most of its growing base of support and activists has been drawn over the last decade.

The longevity of UKIP and its confounding of elite disdain do not in themselves necessarily support the transformational role that Farage claims for his organisation. The party has made some significant inroads in second order elections over the last decade. For example, in 2004, it came third in the European Parliamentary elections, gaining $16.1 \%$ of the vote and increasing its elected representation quadrupled from 3 to 12. In 2009, it gained a further MEP and edged into second place ahead of Labour, the party then holding national office. This achievement was bettered by UKIP's noteworthy performance in the 2013 local government elections, where it averaged $26 \%$ of the vote in the wards where it stood. This was a $10 \%$ increase on its 2012 local election performance and led to the party gaining 147 seats. This was a marked change from the 7 secured in the equivalent elections a few years back in 2009. What had once been seen as a largely single issue party preoccupied with electing MEPs to a body it was vigorously trying to abolish was now broadening its remit and in turn winning over voters with concerted appeals about domestic matters.

At their 2014 spring conference, Farage announced his belief that UKIP could 'win' the European Parliamentary elections due that year and that this would provide them with huge momentum going into the 2015 UK national campaign. On the same day, Farage informed journalists he would resign if his party failed to gain any parliamentary representation at Westminster. This threat represents more of a gamble than it might at first appear because UKIP has never had a candidate elected to parliament and, even in vote share terms, its performance in national campaigns has been modest. In the 2001 election it attracted $1.48 \%$ of the vote or $2.16 \%$ in contested seats. By 2005 these tallies had risen to $2.2 \%$ and $2.8 \%$ respectively and the equivalents for 2010 were $3.1 \%$ and $3.45 \%$. This is steady but unspectacular growth. Unlike other minor parties such as the Greens and Nationalists, UKIP's strength has not been sufficiently geographically concentrated to enable the return of an MP for a given constituency.

The reasons for UKIP's limited impact in first order elections, that is those for Westminster, relates to the party's uncertain electoral base. Ford et al. (2012) demonstrate through a detailed analysis of support in the 2009 European Elections that voters tend to fall into two categories. The first are 'strategic defectors' who are typically affluent, middle class and 
ordinarily Conservatives. These voters have switched to UKIP in second order elections to register opposition to the European Union and dissatisfaction with the performance of the Tory leadership. But they also revert to the Conservatives in General Elections. The other category of UKIP supporters are categorised as 'polite xenophobes'. These are voters who are less affluent citizens, more disaffected with mainstream politics and are attracted by anti-immigration and anti-establishment rhetoric. They are in effect the party's core loyalists and support it across all electoral contexts.

Ford et al. argue that UKIP faces a major dilemma in managing their two distinctive constituencies of support. To retain more support from the 'strategic Eurosceptics' the party needs to cultivate a new, more professional respectability and credibility. But there is an obvious risk because such an approach could in turn alienate the 'polite xenophobes' who value iconoclasm in their politicians. Some argue this creates irreconcilable tensions that mean the party is ultimately 'doomed to fail' as the 'office seeking' ambitions of the leadership come into conflict with the wishes of the membership who want the party to retain its populist, antiestablishment stance (Abedi and Lundberg, 2009). However the most recent successes of UKIP raise questions about this analysis, indicating it is premature in a fast changing political environment where the European Union has sustained and endured major challenges. ${ }^{1}$ But the strategic conundrum facing the party remain as can be gleaned from studying the party's electoral and communication strategy.

\section{Discipline and Diversification: the Evolving UKIP Strategy}

UKIP has been conceptualised as an example of an 'Anti-Political Establishment' (APE) party (ibid.). Such parties have been described as a 'spectre... haunting contemporary party politics' (Schedler, 1996: 291). These insurgent forces' redefinition of 'existing politics as authoritarian' (ibid.) has an inherently right wing affinity that provides a potent populist rallying point for a melange of disaffected floating voters, disgruntled conservatives, overt nationalists and covert racists. Although UKIP undoubtedly shares some of these characteristics, it has not necessarily adopted this mantle in its entirety. There are several explanations why this is the case, notably the fact that the party's anti-establishment stance is not unequivocal and unconditional. Before the 2010 General Election Lord Pearson of Rannoch, a peer of the realm and UKIP's then leader, made an offer to the Conservatives that his party would stand down candidates if a

\footnotetext{
${ }^{1}$ Abedi and Lundberg's analysis was written prior to the 2009 European Elections (in which UKIP gained second place) and against the backdrop of a bloody leadership battle within UKIP in 2004, when the controversial ex-broadcaster, Robert Kilroy-Silk, then a recent recruit to the party, sought to depose the party's leader and pursue an ambitious strategy of 'killing off' the Conservative party. Both strategies were rejected by the party's membership and Kilroy-Silk left the party.
} 
referendum was offered on Britain's membership of the EU. This caused consternation within the party but was a major public confirmation of a more discreet dialogue that had been taking place between politicians on the centre-right fearful of undermining a common cause and benefitting pro-federalist opponents.

A related reason for questioning UKIP's categorisation as an APE force relates to the issue that led to the creation of the party and that continues to define it: British membership of the EU. It is evident that the party's adamantly anti-integrationist stance finds resonance in an increasing Eurosceptic UK public. But the significance of this connection should not be overstated: polling consistently demonstrates that European integration is of marginal and declining significance to electors (Abedi and Lundberg, 2009: 85; Clements et al, 2013). Simultaneously the issue has become marginal to the mainstream media agenda. Successive studies undertaken by the Loughborough Communication Research Centre into news media coverage of UK General Elections since 1997 indicate a campaign-by-campaign reduction in the prominence of the European integration theme. This ranges from 15\% of coverage in 1997 to 1\% by 2010 (see Deacon et al., 1998; Deacon and Wring, 2010). In summary, one of the core problems for UKIP in electoral terms, and one of the drawbacks to characterising the party as an exemplar of the APE paradigm, is that its foundational concern is not a populist one. The European Union is unpopular with a not insignificant section of the electorate but it is of marginal concern when compared with other, more salient issues such as health, education and, of course, the economy.

Aside from the political and electoral reasons for challenging UKIP's portrayal as an APE party, there are organisational grounds for doubting this characterisation. Recent changes in the party have been taking place including a discernable push towards professionalism by the leadership. This is most evident in recent attempts to impose discipline on UKIP representatives. There have been numerous occasions over the years where candidates have made eccentric, offensive and even overtly racist comments in public. For a long time these were tolerated internally as 'going with the territory' of the party's libertarian ethos, even formerly regarded as its Unique Selling Point, revealing the 'individualistic DNA' of UKIP in contradistinction to the dragooned and anodyne professionalism of the mainstream parties (Peev, 2013). This kind of intervention now receives censure from the hierarchy. Perhaps most notoriously there is the case of the now ex-MEP Godfrey Bloom which came to a head in September 2013. Bloom had already attracted controversy for various things including his claim UK Foreign Aid was routinely misappropriated by elites in 'Bongo-Bongo land' to 'buy Ray-Ban sunglasses, 
apartments in Paris, Ferraris and all the rest of it' (London Evening Standard, 7 August 2013). Although he weathered that storm created by his offensive terminology, the party whip was removed the following month after he described a group of women at a fringe meeting as 'sluts' and hit prominent broadcast journalist Michael Crick over the head with the party manifesto after the latter had enquired why the cover of the document had not featured ethnic minority citizens. Leader Nigel Farage had decided there was no longer a place for even prominent spokespeople such as Godfrey Broom because, as he put it, the party needed to now appear 'civilised and grown up'. Further evidence of this harder line came in January 2014, when a UKIP councillor was suspended from membership of the party after he speculated that serious flooding in England constituted a kind of divine retribution from god for the government's decision to approve gay marriage. The party has also recently moved to emphasise its distance from prominent organisations further to the right such as the English Defence League and British National Party, by introducing a unique requirement that all potential candidates sign a form confirming they have 'never engaged in, advocated or condoned racist, violent, criminal or anti-democratic activity... never been a member of or had links with any organisation, group or association which the national executive committee considers is liable to bring the party into disrepute...never been convicted of any offence punishable by a custodial sentence, whether or not a custodial sentence was actually imposed' (Landale, 2014).

Alongside this more disciplined approach, the party has made a concerted attempt to diversify its political portfolio beyond the single issue of European integration. This move to broaden UKIP's remit has resulted in increased scrutiny, particularly from those mainstream media hardly well disposed towards the organisation and its philosophy. For instance on the eve of the 2013 local government elections, several national newspapers reported leaked internal UKIP emails that indicated internal disarray and the possibility that the party would consider buying policies 'off the shelf from right wing think tanks. This was in itself evidence of UKIP struggling to build a credible manifesto that was made difficult through its 'attempts to please its politically divergent support' (Boffey, 2013). This also led to a retrospective analysis by The Times that concluded the party's 2010 manifesto was deeply flawed, to the scale of $£ 120$ billion funding shortfall (Sherman, 2013).

This diversification strategy, a key component in the professionalisation process, has also created internal divisions. For example, In December 2012, Will Gilpin was appointed as Chief Executive with the task of making the party more professional by developing training for staff and candidates and introducing structures and procedures for developing policies. He resigned in 
frustration eight months later, and in an interview with the Daily Telegraph criticised Farage's dominance of the party and complained UKIP remained 'a bunch of enthusiastic amateurs having a good time rather than the professional fighting team they could be' (Kirkup and Laurence, 2013). In noting the ongoing difficulties the party is experiencing in developing a credible and diverse portfolio, it is important to not underestimate the scale of the transitions that have already occurred.

In the 2010 General Election Farage promised the 'edgiest campaign in history' and this quality manifested in two distinct changes of direction in the focus of the campaign. First, the party sought to accentuate its 'anti-establishment' credentials through seeking to connect with growing public disillusionment with mainstream politicians over the MPs' expenses scandal of 2009. This theme was most stridently articulated in a poster depicting the three main party leaders under the headline slogan 'Sod The Lot'. At UKIP's manifesto launch, Farage declared: '(F)rankly, the campaign so far has been a piddling irrelevancy and it's becoming increasingly clear that the choice the British public are being offered here is not for a change of government but for a change of management' ('Ukip's short, sharp message: Sod the lot', Northern Echo, 14 April 2010). This populist impulse was reinforced by the second key focus of the campaign, specifically on immigration policy and the party's manifesto commitment to introduce a five year freeze on immigration and thereby ensure 'that any future immigration does not exceed 50,000 people per annum'. Taken together the centre-staging of integrity and immigration provided UKIP with a far more populist platform than integration alone. Furthermore, they offered ways of popularising the party's Eurosceptic agenda, on the one hand by denouncing the EU as an exemplar of non-accountability, political corruption and bureaucratic inefficiency; and on the other as the institution most responsible for the alleged 'flooding' of the country by migrant, particularly from newer member state countries.

At first sight, it might seem that the discipline and diversification strategies are creating greater paradoxes for the party; as in presentational and organisational terms, UKIP seems to be cultivating its mainstream respectability, whereas in policy terms, it is promoting and asserting its anti-establishment and populist credentials. But these tensions may not be as irreconcilable as they first appear, when we consider how the parameters of political discussion in the UK have altered recently regarding the three cornerstones of UKIP's core campaign agenda: integration, immigration and integrity ${ }^{2}$. To take the issue of European integration first, where once discussion was devoted to arguing for reforms of the terms for UK membership, it is now more

\footnotetext{
${ }^{2}$ Our thanks to Sam Marston for contributing to our analysis on this point (see Marston, 2014).
} 
likely to countenance the prospect of the country leaving the Union. David Cameron's recent announcement that Britain would hold an in/out referendum by 2017 on withdrawing from the EU in the event of his being re-elected Prime Minister underlines UKIP's success in reengineering the essentials in this debate. With respect to integrity, research shows public trust in politicians and government have reduced significantly in the wake of political scandals, such as the controversy about politicians' abuse of personal expense allowances that broke in 2009. In the keynote findings of the 2013 British Social Attitudes survey it was noted that 'While a degree of scepticism towards politicians might be thought healthy, those who govern Britain today have an uphill struggle to persuade the public that their hearts are in the right place' (Clery et al., 2013). Regarding immigration, UKIP's reiteration of its opposition to what it regards as excessive levels has connected with the preoccupations of many right wing news organisations on this issue and their belief that liberal orthodoxy has stifled and curtailed proper debate (Deacon and Wring, 2010). This has started to resonate more widely across the media mainstream, for example, being the subject of a recent prime time documentary authored by the BBC political editor Nick Robinson (Robinson, 2014). At the same time, politicians, notably those belonging to the interior ministry headed by Home Secretary Theresa May, have launched initiatives that can be seen as part of governmental attempts to be doing something to tackle the 'crisis'. The most high profile of these has been a mobile advertising campaign featuring the slogan 'Go Home'. If the blunt message proved controversial then so did the deployment of the vehicles displaying it to areas traditionally home to non-white immigrant communities. Ironically, this particular policy was dismissed as a nasty and unhelpful stunt by Farage who also acknowledged the initiative owed something to his party's growing ability to influence and shape public perceptions and the wider agenda:

'What the billboards should say is please don't vote UKIP, we're doing something.

That's what it's all about, of course it is. I think the actual tone of the billboards is nasty, unpleasant, Big Brother. It'll make no difference. I don't think using messages like this will make any difference, what will make a difference is enforcing our borders properly' (Groves, 2013).

In noting how conducive the terms of much contemporary political discourse is for UKIP's agenda, we are not suggesting that the party is responsible for creating this new climate of debate. Indeed, in our view, it is more probable that UKIP is a dependent rather than independent factor, benefiting from wider political trends rather than initiating them. But this is 
not to deny how the party's political opportunism has served to accelerate and accentuate public and media discussion of these matters.

The perceived potency of UKIP both as an electoral and agenda-setting force devoted to transforming the British political landscape has understandably attracted considerable and growing interest. Determining whether the party is successfully moving 'towards the mainstream' (Hayton, 2010) and thereby 'coming of age as a permanent force in UK politics' (BBC, 2014) or is else likely 'doomed to failure' (Adebi and Lundberg, 2009) may be determined by its performance in the 2015 General Election. Nigel Farage has, as has already been noted, announced he will resign his leadership if UKIP fails to make inroads through winning parliamentary representation in this first order election. This is evidence of his determination to convince commentators, particularly in the mainstream media, that his is a serious potential power broker with ambitions to rapidly move from the periphery to the centre of debate. Farage will be acutely aware that the more Eurosceptic minded newspapers in Britain could be pivotal to this strategy.

This UK wide national press has long enjoyed an influential opinion-forming role in British politics. Many of the major titles have made their partisanship a distinctive aspect of their identity if not necessarily their appeal. Elections provide an obvious and important opportunity to consider this factor because they offer the arena in which the fullest and widest exposition of editorial discourses are mobilised. Furthermore these printed titles have long exerted influence in 'formatting' public debate on a range of topics (Seaton, 1995: 134). Of particular significance here is the degree of connection between UKIP and the more populist newspapers: while these media are inclined to share some of the defining concerns of the party, their approval cannot be presupposed. This is because, as Krämer argues, media populism and populism per se are not necessarily the same thing and there is a need to be sensitive to the varying occasions when the former acts as 'a substitute or competitor to populism in the political landscape... when do they contribute to its containment and in what cases is there a symbiosis or positive feedback between them?' (2014: 57). Although newspapers may be well habituated in expressing their discontent with many aspects of existing political culture, their accompanying role as 'legitimating tools of the social and political order' cannot be disregarded (Mazzoleni, 2003: 10).

The remainder of this chapter will focus on the media and review the major trends and changes in national press reporting of UKIP in the 2001 and 2010 UK General Election campaigns. This commentary is based on content analysis of the major daily and weekly national 
newspapers published in the 28 days up to polling day in both years, namely: The Times, Sunday Times, Guardian, Observer, Independent, Independent on Sunday, Daily Telegraph, Sunday Telegraph, Daily Mail, Mail on Sunday, Daily Express, Sunday Express, Daily Mirror, Sunday Mirror, Daily Star, Star on Sunday and Sun although not its News of the World sister (see note ${ }^{3}$.

\section{UK National Press General Election coverage of the UK Independence Party: Enthusiasm, Indifference or Indignation?}

The most obvious issue to address in assessing the reporting of any given party is to establish the extent to which it has established and developed its news presence in the hypercompetitive arena of a General Election. Table 1 quantifies the number of items that contained any editorial reference to UKIP in the 2001 and 2010 UK campaigns, differentiating between those items that had the party as a main or prominent focus in an item and those that referred to it in an incidental way. The results show that aggregate coverage of the party more than doubled, although this was starting from a relatively low base of 123 items in 2001 to 256 items by 2010 . The number of prominent references to UKIP also increased from 42 to 77 but not proportionally. In 2001 the ratio of main to incidental references was 1 to 1.9; in 2010 it was 1 to 2.3 .

Table 1. Prominence of UKIP in General Elections: Items by Newspaper and Campaign

\begin{tabular}{|l|l|l|l|l|}
\cline { 2 - 5 } \multicolumn{1}{c|}{} & $\mathbf{2 0 0 1}$ & $\mathbf{2 0 1 0}$ & \\
\cline { 2 - 5 } & $\begin{array}{l}\text { Principal } \\
\text { focus }\end{array}$ & $\begin{array}{l}\text { Incidental } \\
\text { reference }\end{array}$ & $\begin{array}{l}\text { Principal } \\
\text { focus }\end{array}$ & $\begin{array}{l}\text { Incidental } \\
\text { reference }\end{array}$ \\
$\begin{array}{l}\text { Dailies } \\
\text { Guardian }\end{array}$ Times & 5 & 14 & 15 & 57 \\
Daily Telegraph & 7 & 11 & 8 & 24 \\
Independent & 14 & 12 & 7 & 20 \\
Daily Express & 5 & 18 & 5 & 16 \\
Daily Mail & 4 & 3 & 14 & 9 \\
Sun & 3 & 3 & 4 & 13 \\
Daily Mirror & 1 & 3 & 2 & 4 \\
Daily Star & 1 & 5 & - & 3 \\
\hline
\end{tabular}

\footnotetext{
${ }^{3}$ Relevant items were identified by using the keywords 'UKIP' and/or 'UK Independence Party' to search the Nexis newspaper database. The resulting content was then vetted following the principles set out in Deacon, 2007 (i.e. all false positives and duplicated content were removed and tests were conducted to ensure that there were no general gaps in the coverage of the data base that might produce 'false negatives' [this was found to be the case with News of the World content]). To ensure comparability, we excluded all material that was only published on titles' web only content (for example, the Telegraph and Sunday Telegraph included blogs in 2010). We also ignored items that solely logged UKIPs candidacy in particular constituencies.
} 


\begin{tabular}{|l|l|l|l|l|}
\hline Sundays & - & 2 & 3 & 4 \\
Observer & - & 5 & 6 & 7 \\
Sunday Times & - & 1 & 1 & 6 \\
Independent on Sunday & 1 & 2 & 2 & 5 \\
Sunday Telegraph & 1 & 1 & 2 & 2 \\
Mail on Sunday & - & - & - & 2 \\
The People & - & 1 & 4 & 5 \\
Sunday Express & $\mathbf{4 2}$ & $\mathbf{8 1}$ & $\mathbf{7 7}$ & $\mathbf{1 7 9}$ \\
\hline Total & & &
\end{tabular}

The detailed title-by-title comparison in Table 1 reveals some surprising results. The first is that this purportedly populist party attracted negligible coverage in the most popular titles. Across both elections, the Sun, Mirror, Star and People only ran 21 items that made any reference to UKIP, and only four of which had it as a main or significant point of focus. The Sunday Mirror made no reference to the party at all in its coverage of both campaigns. These results may in part be explained by the general lack of sustained engagement of the popular so-called 'redtop' titles with the formal conduct of recent General Elections (for more on this see Deacon et al, 2001: 668; Deacon et al., 2006). That said, UKIP's lack of traction with even the most popular titles is striking, particularly in 2010 following the recent changes in its campaigning focus. In terms of the mid-market or 'blacktop' titles, there was some apparent difference between the Mail/Mail on Sunday and Daily Express/Sunday Express. While neither pair has increased its coverage dramatically, it is noticeable that the Express titles were carrying more items with UKIP as their main or sole focus by 2010 .

Table 2. Coverage of UKIP in General Elections: type of item published

\begin{tabular}{|l|l|l|l|l|}
\cline { 2 - 5 } \multicolumn{1}{c|}{} & $\mathbf{2 0 0 1}$ & & $\mathbf{2 0 1 0}$ & \\
\cline { 2 - 5 } \multicolumn{1}{c|}{} & $\begin{array}{l}\text { Principle } \\
\text { focus }\end{array}$ & $\begin{array}{l}\text { Incidental } \\
\text { reference }\end{array}$ & $\begin{array}{l}\text { Principle } \\
\text { focus }\end{array}$ & $\begin{array}{l}\text { Incidental } \\
\text { reference }\end{array}$ \\
\hline $\begin{array}{l}\text { News } \\
\text { Feature } \\
\text { Comment } \\
\text { Editorial } \\
\text { Letter } \\
\text { Other }\end{array}$ & 21 & 32 & 27 & 36 \\
\cline { 2 - 5 } & 2 & 22 & 14 & 48 \\
\hline Total & - & 22 & 25 & 82 \\
\cline { 2 - 5 } & 10 & - & 2 & 3 \\
\hline
\end{tabular}


Possible explanations for the growing Express coverage of UKIP will be discussed after further consideration of the supposed 'quality' newspapers. Here the amount of reporting of UKIP did not correlate with a given title's editorial stance on the integration question. The traditionally more Eurosceptic print media such as the Daily Telegraph, Sunday Telegraph, The Times and Sunday Times did not devote appreciably greater coverage than those of their rivals who were inclined to take a more detached approach to reporting EU related matters. Indeed, the main outlier in 2010 and exemplar of the latter tendency was the Guardian, whose coverage of UKIP far exceeded that of its competitors among the elite opinion-forming titles.

Table 2 disaggregates the figures for coverage according to item type and thereby adds a further perspective on the increased national press presence of UKIP by 2010. This was mainly due to increases in the number of references made to the party in feature items and commentaries. By comparison 'hard' news coverage, providing factual reporting about the actions and activities of UKIP, increased but only negligibly. The party also received scant mention in editorials, which is significant because these pieces are often important indicators of a given newspaper's political concerns and orientations (Deacon and Wring, 2002: 200). The two editorials that gave prominence to UKIP both appeared in 2010 and were published in titles that have long harboured Eurosceptic tendencies. For its part The Times was exercised by Nigel Farage's decision to stand as a candidate in the constituency of the current Speaker of the House of Commons, John Bercow, thereby flouting a longstanding convention that the holder of the post is able to stand unopposed by rival parties in order to ensure they can continue to fulfil their constitutional duties from a position of partisan independence. The editorial item in question delivered a withering assessment of Farage, who had temporarily stepped down from the party leadership to devote his energies to campaigning as parliamentary candidate for Buckingham:

'The fact that the person seeking to unseat [Bercow] - UKIP's publicity-craving, permablazered Nigel Farage - is the sort of man to whom people take an instant dislike, because it saves time; a man so lacking in charisma that he manages to give cravats an even worse name than they already have...Mr Farage accuses Mr Bercow of representing "all that is wrong with British politics today". Really? We had Mr Farage down for that' (The Times, 2010) 
The editorial in the Daily Express, published on the eve of polling day, was appreciably more sympathetic in its comments about UKIP and its erstwhile leader. Pointedly it even encouraged those who could to vote for Farage over Bercow. But the editorial also cautioned readers about the danger of undermining support for the Conservatives through the splitting of the centre-right vote:

'Following the parliamentary expenses scandal of last year, many readers may still be considering a vote for one of the smaller parties. We hope that nobody will back the poisonous BNP, whose attempt to create a hierarchy of British subjects based upon racial background is fundamentally un-British. No such disqualification applies to UKIP. Under Lord Pearson it has set out attractive policies on everything from relations with the EU to education, taxation and law and order. But UKIP cannot win this election and in many constituencies a vote for it is likely to increase the risk of a pro-EU socialist being returned rather than a sensible Conservative.

There are exceptions, such as in Buckingham, where this newspaper would love to see Nigel Farage unseat the Commons Speaker John Bercow - nominally still a Tory but the sort of Tory who has climbed the greasy pole by agreeing with most items of Labour policy. But in general, a UKIP vote tomorrow will risk keeping Brown in Downing Street by depriving Conservatives of vital extra seats and that would be a tragedy (Daily Express, 2010).

The rare acknowledgement and expression of sympathy for UKIP by a mainstream newspaper at such a momentous time in the electoral cycle points to a growing rapprochement between the party and at least one major proprietor. Consequently it will be instructive to further consider and monitor the developing editorial responses of Express group titles (Daily Express, Sunday Express, Star and Star on Sunday) towards UKIP. It has already been noted that cumulatively these titles were giving more prominence to the party than rival publications by 2010. On one particular occasion this translated into a more fulsome endorsement in which the Sunday Express ran an 871 word piece by a former MP entitled: 'voting is the best form of protest'. The piece lamented what it perceived to be the travails of the country and the failings of the main parties. Towards the end it concluded:

'None of the major parties tells the truth about the scale of the task that lies ahead... For heaven's sake, don't waste your vote by abstaining. Of the three main parties, the Tories with all their deficiencies are unquestionably the best choice. If you can't face 
them, make a positive protest. Kidderminster has twice elected independent Dr Richard Taylor. UKIP got 16 per cent in the Euro elections and advocates the straight talking the country needs.

Rather than abstain, vote to throw the rascals out. Nothing would do more to send a shockwave through our moribund political system than a strong showing by a respectable alternative like UKIP or an independent like Esther Rantzen in Luton (Daily Express, 2010).

The analysis contained in the Express piece conveyed a key message of the UKIP campaign, specifically that by endorsing it voters were not wasting their ballots. This was a major theme that the party attempted to get across in order to establish its credentials in future first order elections. Perhaps unsurprisingly the author of the Express commentary, former Conservative government minister Neil Hamilton, became a member of UKIP in 2002 and was appointed as Deputy Chair in late 2013. In early 2014, Hamilton was joined by another, more prolific Express contributor Patrick O'Flynn who resigned as Chief Political Commentator of the newspaper group to become the party's Director of Communications and also a candidate who is set to be elected to the European Parliament in the forthcoming poll.

The most significant change in the national press representation of UKIP between 2001 and 2010 was in the issues it was associated with. Whereas in 2001 items about the singular European integration issue dominated coverage of the party, by 2010 immigration and integrity had emerged to complement and diversify this reporting (see Figure 1). Table 3 shows what other topics were linked to UKIP in coverage. At first sight, the results for 2010 suggest that there was an increased diversification in the topics with which UKIP was associated, but the really significant point to note is the infrequency with which coverage linked UKIP to issues beyond immigration, integrity or integrity. In media terms, UKIP moved from being a one-trick pony to a three-trick pony, but beyond these expanding core concerns the party contributed very little to the wider terms of national press electoral debate.

Figure 1. General Election Reporting of UKIP: the growth and diversification in the party's coverage. 


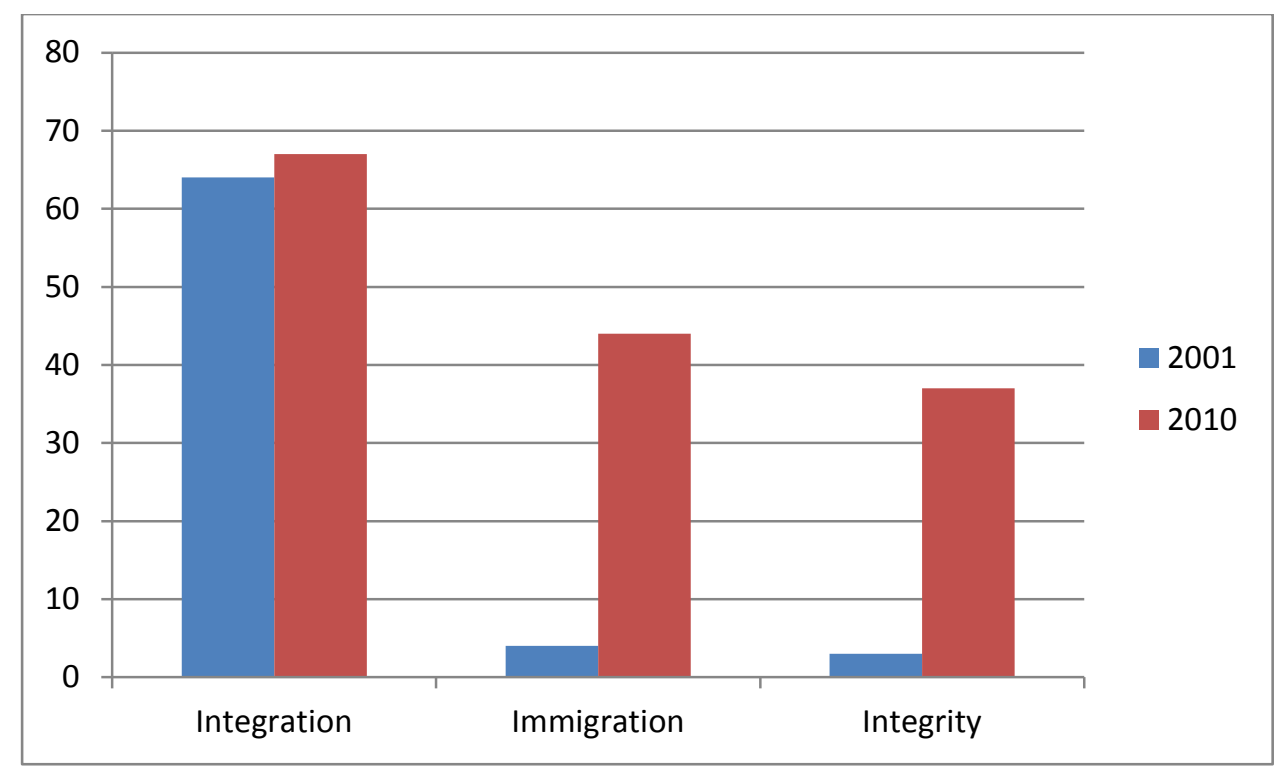

Notes: The three categories are separate (i.e. individual items could mention some, all or none of these three topics)

Table 3. UKIP General Election Coverage: other topics

\begin{tabular}{|l|l|l|}
\cline { 2 - 3 } \multicolumn{1}{c|}{} & \multicolumn{2}{l|}{ Election } \\
\cline { 2 - 3 } \multicolumn{1}{c|}{} & $\mathbf{2 0 0 1}$ & $\mathbf{2 0 1 0}$ \\
\hline Business & 3 & 2 \\
Constitutional Issues & 2 & 4 \\
Crime/Law and Order & 10 & 2 \\
Defence/Diplomacy & - & 1 \\
Economy & 3 & 1 \\
Education & - & 2 \\
Environment & - & 3 \\
Farming/Agriculture & - & 1 \\
Health & - & 3 \\
Public Services & - & 1 \\
Social Security & - & 1 \\
Taxation & - & 1 \\
Transport & 3 & 3 \\
Other & 1 & 3 \\
\hline Totals & $\mathbf{2 2}$ & $\mathbf{3 4}$ \\
\hline
\end{tabular}

\section{Summary and conclusion}

In this discussion we have examined the rise and sustained political presence of the UK Independence Party. The vagaries of the British electoral system were once said to be anathema to a smaller party making significant headway and gaining representation. The last few decades have undermined this assumption with the emergence of challengers such as the Nationalists, Greens and single-issue candidates who have been able to channel local grievances and regularly 
win seats at Westminster. Similarly, the Liberal Democrats have demonstrated the efficacy of targeting resources on certain winnable constituencies. By contrast, and more than a little ironically, UKIP has greatly benefitted from the system of proportional representation adopted for the European Union elections in 1999, giving it enormous scope to develop as a party. Its sizeable, now established group of representatives at Brussels and Strasbourg provide resources and a vital political platform for reiterating its core proposition: withdrawal.

The first part of this chapter has charted how UKIP has developed its campaigning, partly out of recognition that its anti-integration message is an insufficient means for exerting wider political influence. Alongside political diversification, it has attempted to introduce more discipline to its political organisation and activities, although this remains a work in progress. The second part of the discussion examined mainstream newspaper responses to the party and its changing strategies in 'first order' election contests, the domains where UKIP needs to establish a significant presence if they are to gain any parliamentary presence. The findings reveal that UKIP made modest gains between 2001 and 2010: achieving more media exposure from a low base and a more diverse policy presence. Overall, the results find scant evidence of any 'mediatic legitimization' (Mazzoleni, 2003: 7) for its activities from these quarters, in these contexts. With the qualified exception of the Express, even the more Eurosceptic newspapers either ignored or raised doubts about the party. The popular press hardly reported on the party in either election and UKIP's increased presence in 'quality press' coverage was mainly explained by an increase in reportage (commentaries and features) rather than reporting (hard news). In 2010, UKIP added to the colour rather than the content of the campaign, with many of the comment pieces variously focusing on the eccentricities, inconsistencies, intemperance and amateurishness of its representatives (which can hardly be construed as 'on message' with the party's strategy to professionalise). UKIP's failure to achieve greater prominence in news coverage in 2010 is even more significant when one considers that immigration and integrity were very much on the election news agenda at the time (see Deacon and Wring, 2010). It is evident that UKIP has so far failed to establish itself in the eyes of the national press as a significant 'political leadership arena' (Seymoure-Ure, 1987) in General Election contexts, even on the hot button issues it campaigns upon.

The key question is whether this is likely to change in the 2015 General Election? Recent developments in the lead up to the 2014 European elections raise some suggestive indications that this could lead to a breakthrough. There is growing evidence that anxiety about UKIP has started to mobilise a 'get Farage' campaign within the Conservative supporting media (Jones, 2014), the most recent manifestation of which was a series of exposes in the Daily Mail and Sun 
newspaper about Nigel Farage's private life. Although this is not the kind of coverage any politician ordinarily covets, Farage has prided himself on his maverick status and is therefore perhaps better placed to face down such criticisms of this kind than his mainstream rivals. But it should also be noted that while allegations concerning his supposed marital infidelity might not be so damaging, claims that he employed his alleged lover as a personal aide using the funds available to him as an MEP could prove more problematic and undermine his party's previous campaigning over the MPs' expense scandal. That said, such exposure might ultimately be regarded as a kind of marker of success and how far UKIP has come. It is difficult to imagine the Green's Natalie Bennett, leader of the other countrywide formation with elected representation at various levels of government, achieving anything like this kind of name recognition on the front-pages of the two best-selling daily newspapers. On the surface the recent expose has been about a so-called 'human interest' story, but its prominence underlines the now established fear that UKIP has become increasingly able to set the 'hard news' reporting agenda and this at a crucial period in the electoral cycle.

At the same time, it is evident that UKIP is exerting greater presence and influence in other national media contexts. On 31 March 2014, Channel 4 ran an hour long documentary 'Nigel Farage - Who Are You?' by Martin Durkin, which was based on 6 month's access to the UKIP leader. It was a largely sympathetic portrayal by a film maker who declared himself in the film as 'a wicked, middle aged, libertarian' and which in the view of the Daily Telegraph's TV critic produced a portrait that 'was so cloying even UKIP fans would find it sickly' (Midgley, 2014). In the same month, OFCOM ruled that UKIP should be deemed by broadcasters as a major party for the 2014 European election, which means it will be entitled to equivalent amounts of Party Election Broadcasts and election coverage as the main political parties (with exemptions made for Scotland, where UKIP commands little public support). This raises the possibility that it could be similarly defined in the 2015 General Election, thereby strengthening Nigel Farage's insistence that he participate in any televised leaders' debates. This would have an exponential impact on the party's exposure across all media sectors throughout the campaign.

Also in March 2014, Nigel Farage and Deputy Prime Minister and LibDem leader Nick Clegg began a series of live broadcast debates for the 2014 European Election that replicated the kind that dominated the 2010 General Election agenda. The joint move is perhaps mutual recognition that both politicians might exploit this increased media exposure to take votes off the major parties, if not each other. Significantly, unlike Clegg, Farage's stridently anti-federalist message finds resonance in more populist UK print titles such as the Sun and Mail, and just days after reporting allegations about the UKIP leader's personal conduct, these papers gave 
considerable prominence to opinion poll data that suggested Farage had 'won' the first debate. It is difficult not to see the apparent inconsistencies and contradictions in these editorial responses as emblematic of wider uncertainties among journalists and politicians about UKIP's future role and influence in the British political firmament.

\section{References}

Abedi, A. \& Lundberg, T. (2009) 'Doomed to Failure: UKIP and the Organisational Challenges Facing Right-Wing Populist Anti-Political Establishment Parties', Parliamentary Affairs, 62 (1): 72 87

Addley, R. (2013) 'UKIP Conference: It's Easy to Mock, But They Like It', The Guardian, 20 September.

BBC (2013) 'UKIP has signed up 13,000 new members since 2013', BBC News online, 31

December

BBC (2014) Politics Show, broadcast BBC1 $2^{\text {nd }}$ March.

Boffey, D. (2013) 'Ukip in Chaos Over Policy on Eve of Key Poll, Emails Reveal', The Observer, 27 April, p.1

Clements, B., Lynch, P. and Whitaker, R. (2013) The low salience of European integration for British voters means that UKIP will have to expand their platform to gain more support. LSE European Politics and Policy (EUROPP) Blog Entry, $8{ }^{\text {th }}$ March.

Clery, L., Park, A., Phillips, M., Lee, L. Taylor, E., Finnegan, J. and Cullinane, C. (2013) British Social Attitudes Survey, No.30, London: Natcen.(http://bsa-30.natcen.ac.uk/read-the-report/keyfindings/trust,-politics-and-institutions.aspx, accessed 1 April 2014)

Copus, C., Clark, A., Herwig, R and Kristof, S. (2009) 'Minor Party and Independent Politics beyond the Mainstream: Fluctuating Fortunes but a Permanent Presence', Parliamentary Affairs, 62(1): 4-18.

Deacon, D. and Wring, D. (2002)

Deacon, D. Golding, P. and Billig, M. (1998) 'Between Fear and Loathing: National Press

Coverage of the 1997 General Election' in Denver, D., Fisher, J., Cowley, P. and Pattie, C. (eds)

British Elections and Parties Review, Volume 8

Deacon, D., Golding, P. and Billig, M. (2001) 'Press and Broadcasting: 'Real Issues' and Real Coverage', Parliamentary Affairs, 54(4): 666-678.

Deacon, D., Wring, D. and Golding, P. (2006) 'Same Campaign, Differing Agendas', British Politics, 1: 222-256. 
Deacon, D. (2007) 'Yesterday's Papers and Today's Technology: Digital Newspaper Archives and "Push Button" Content Analysis', European Journal of Communication, Vol 22(1): 5-25.

Deacon, D. and Wring, D. (2002) 'Partisan Dealignment and the British Press', in Bartle, J., Mortimore, R. and Atkinson, S.(eds.) Political Communications: the British General Election of 2001. London: Frank Cass, pp.197-211.

Deacon, D. and Wring, D. (2010) 'Reporting the 2010 General Election: Old Media, New Media - Old Politics, New Politics' in Wring, D., Mortimore, R. and Atkinson, S. (eds) Political Communication in Britain: The Leader's Debates, the Campaign and the Media in the 2010 General Election Basingstoke: Palgrave Macmillan.

Denver, D. and Garnett, M. (2014) British General Elections since 1964. Hampshire: Palgrave Macmillan.

Ford, R., Goodwin, M., Cutts, D. (2012) 'Strategic Eurosceptics and Polite Xenophobes: Support for the United Kingdom Independence Party in the 2009 European Party Elections', European Journal of Political Research, 51: 204-234.

George, S. (1998) An Awkward Partner: Britain in the European Community. Oxford: Oxford University Press.

Grant, W. (1989) Pressure Groups, Politics and Democracy in Britain, London: Philip Allen

Groves, J. (2013) 'Tory posters telling illegal immigrants to 'Go Home' branded 'nasty' by UKIP's Farage as Lib Dems demand they be 'shredded now', Daily Mail $25^{\text {th }}$ July

Jones, O. (2014) 'Operation Get Nigel Farage is politics of the lowest form', the Guardian, 13 March.

Kirkup, J \& Laurence, J (2013) 'Nigel Farage Wants UKIP to Remain “A Bunch of Amateurs" Daily Telegraph, 20 August

Krämer, B. (2014) 'Media Populism: A Conceptual Clarification and Some Theses on its Effects', Communication Theory, 24(1): 42-60.

Landale, J. (2014) UKIP: 'No skeletons in my cupboard', BBC News, 28 February (http://www.bbc.co.uk/news/uk-politics-26385178, accessed 26 March 2014)

Marston, S. (2014) A completed "life-cycle": UKIP's transition from an anti-political-establishment party into the mainstream?, Undergraduate dissertation submitted to the Department of Politics, History and Industrial Relations, Loughborough University.

Mazzoleni, G. (2003) 'The Media and the Growth of Neo-Populism in Contemporary Democracies' in Mazzoleni, G., Stewart, J. and Horsfield, B. (eds) (2003) The Media and NeoPopulism: A Contemporary Comparative Analysis, Westport: Praeger

Midgley, N. (2014) Nigel Farage: Who Are You?, Channel 4, review', Daily Telegraph, 1 April. NatCen (2013) 
Peev, G. (2013) 'UKIP chief walks out after only eight months after struggling to adapt to 'individualistic DNA' of the party', Daily Mail, 21 August.

Robinson, N. (2014) 'The Truth About Immigration', broadcast BBC2, $7^{\text {th }}$ January (http://www.bbc.co.uk/mediacentre/proginfo/2014/01/nick-robinson-immigration.html)

Schedler, A. (1996) ‘Anti-Political-Establishment Parties’ Party Politics 2.3: 291-312

Seaton, J. (2005) Carnage \& the Media: The Making \& Breaking of News About Violence London: Penguin

Seymoure-Ure, C. (1987) 'Leaders' in Pimlott, B. and Seaton, J. (eds) The Media in British Politics, Aldershot: Avebury.

Sherman, J. (2013) 'UKIP dream for a better Britain Vanishes into a ' $£ 120$ bn Black Hole', The Times, 29 April, p.9. 